\title{
DOI: http://dx.doi.org/10.33846/sf11213
}

Edukasi Senam Kaki Berpengaruh Terhadap Self Care pada Pasien Diabetes Mellitus

Dewi Wijayanti

Prodi DIII Keperawatan, Universitas Borneo Tarakan; dewi.wijayanti8386@gmail.com (koresponden)

\begin{abstract}
Education is one of the basic factors that can condition a person to be able to improve their abilities, knowledge, skills and attitude. The process of understanding patients with diabetes mellitus can occur through health education, by providing information, so there will be an awareness of individuals to behave in accordance with the knowledge they have. This study aims to analyze the effect of foot gymnastics education on self care in patients with diabetes mellitus at Panembahan Senopati Hospital, Yogyakarta. This quasiexperimental study used pre-test and post-test with control group design. The results showed that foot gymnastics education affected self care in patients with diabetes mellitus, with a p-value $=0.000$.

Keywords: diabetes mellitus; foot gymnastics education; self care
\end{abstract}

\begin{abstract}
ABSTRAK
Edukasi merupakan salah satu faktor dasar yang dapat mengkondisikan seseorang untuk dapat meningkatkan kemampuan, pengetahuan, ketrampilan dan sikap diri. Proses pemahaman pasien diabetes mellitus dapat terjadi melalui pendidikan kesehatan, dengan memberikan informasi, sehingga akan timbul kesadaran pada individu untuk berperilaku sesuai dengan pengetahuan yang dimilikinya. Penelitian ini bertujuan menganalisis pengaruh edukasi senam kaki terhadap self care pada pasien diabetes mellitus di Rumah Sakit Panembahan Senopati, Yogyakarta. Penelitian eksperiment kuasi ini menggunakan pre-test and post-test with control group design. Hasil penelitian menunjukkan bahwa edukasi senam kaki berpengaruh terhadap self care pada pasien diabetes mellitus, dengan p-value $=0,000$.
\end{abstract}

Kata kunci: diabetes mellitus; edukasi senam kaki; self care

\section{PENDAHULUAN}

Diabetes mellitus (DM) merupakan kelompok penyakit metabolik dengan karakteristik hiperglikemia yang terjadi karena adanya gangguan metabolisme karbohidrat, lemak dan protein, sehingga mengakibatkan kelainan sekresi insulin dan kerja insulin atau kedua-duanya. Secara klinis terdapat dua tipe penyakit ini yaitu DM tipe I yang disebabkan adanya gangguan metabolik yang ditandai oleh kenaikan kadar gula darah akibat kerusakan sel beta pancreas karena suatu sebab tertentu yang menyebabkan produksi insulin tidak ada sama sekali, sehingga penderita sangat memerlukan tambahan insulin dari luar; dan DM tipe II yang merupakan kasus terbanyak (90\%-95\%) dari seluruh kasus diabetes, yang umumnya mempunyai latar belakang kelainan dengan resistensi insulin. ${ }^{(1)}$

Prevalensi DM semakin meningkat dari tahun ketahun. Organisasi kesehatan dunia (WHO) menyatakan bahwa pada tahun 2006, sedikitnya 171 juta orang mengalami DM dan akan meningkat dua kali lipat pada tahun 2030. WHO menyimpulkan bahwa pada tahun 2010 Indonesia menempati urutan ke-4 terbesar di dunia setelah India, China, dan USA dalam jumlah penderita diabetes di dunia. DM di Indonesia menempati urutan ke 3 dari 10 besar penyakit mematikan setelah stroke menempati urutan ke 1 dan dan ischemic heart disease diurutan kedua. ${ }^{(2)}$

Laporan Riset Kesehatan Dasar menunjukkan bahwa prevalensi DM pada tahun 2015 (2,1\%) mengalami peningkatan dibandingkan pada tahun $2013(1,1 \%)$, dimana prevalensi DM tertinggi terdapat di Provinsi D.I Yogyakarta, dengan prevalensi 2,6\%, yang kemudian diikuti oleh DKI Jakarta $(2,5 \%)$ dan Sulawesi utara (2,4\%). Laporan Survailans Terpadu Penyakit (STP) Puskesmas dan Sistem informasi Rumah Sakit (SIRS) di provinsi D.I Yogyakarta pada tahun 2014 menunjukkan bahwa terdapat 17.434 kasus DM, di mana penyakit DM menempati urutan ke 5 dari 10 besar penyakit di D.I Yogyakarata. ${ }^{(3)}$

Setiap tahun menunjukan peningkatan pasien DM yang signifikan di RSUD Panembahan Senopati Bantul, Yogyakarta. Berdasarkan laporan Informasi Rumah Sakit (SIRS) RSUD Panembahan Senopati Bantul Yogyakarta, menunjukan bahwa penyakit DM selalu berada di peringkat 10 besar penyakit. Berdasarkan data SIRS berbasis rawat inap jumlah kasus penyakit DM pada tahun 2014 sebanyak 339 kasus dan tahun 2015 sebanyak 462 kasus DM, sementara kasus diabetes mellitus berbasis rawat jalan pada tahun 2014 sebanyak 6.653 kasus DM dan tahun 2015 sebesar 9.730 kasus DM. $^{(4)}$

Self care adalah teori keperawatan yang dikemukakan oleh Dorothea E Orem, yaitu suatu pelaksanaan kegiatan yang didasarkan atas kesadaran diri dan dilakukan oleh individu itu sendiri untuk memenuhi kebutuhan dalam mempertahankan kehidupan, kesehatan, dan kesejahteraan sesuai dengan keadaan baik sehat maupun keadaan sakit. ${ }^{(5)}$ Upaya kemandirian yang dilakukan oleh pasien DM disebut dengan self care DM, di mana self care DM merupakan tindakan yang dilakukan seseorang untuk mengontrol DM dalam pencegahan komplikasi. 
Gambaran tingkat self care pada pasien DM sangat rendah, yakni self care dalam latihan fisik dan perawatan kaki, sehingga pasien DM rentan mengalami komplikasi kronik baik mikroangiopati maupun makroangiopati. Komplikasi DM terjadi pada semua organ tubuh dimana salah satu komplikasi yang sering dijumpai adalah kaki diabetik (diabetic foot), yang dapat bermanifestasikan sebagai ulkus, infeksi gangren dan artropati. ${ }^{(6)}$

Tindakan yang mendukung pengelolaan DM adalah tindakan perawatan secara mandiri (self care), dikarenakan DM merupakan penyakit kronis yang umum terjadi pada dewasa yang membutuhkan supervisi medis berkelanjutan. Bentuk perawatan mandiri pada pasien DM meliputi pengaturan nutrisi, aktivitas fisik, penggunaan obat dan monitoring glukosa darah, bentuk self care bukanlah hal yang mudah bagi pasien DM, di mana pasien DM harus memiliki keinginan, kesadaran diri yang tidak lepas dari informasi tentang kesehatannya dan edukasi yang telah didapatkan untuk penanganan penyakit yang diderita secara mandiri. ${ }^{(7)}$

Edukasi merupakan salah satu faktor dasar yang dapat mengkondisikan seseorang untuk dapat meningkatkan kemampuan, pengetahuan, ketrampilan dan sikap diri, dimana proses pemahaman pasien DM dapat terjadi melalui pendidikan kesehatan, dengan memberikan informasi sehingga akan timbul kesadaran pada individu atau masyarakat untuk berperilaku sesuai dengan pengetahuan yang dimilikinya. Edukasi diberikan dengan tujuan agar informasi tentang penyakit diabetes mellitus tersampaikan dengan benar dan tepat pada pasien, sehingga pasien dapat merasakan bahwa dirinya lebih sehat, dapat mengontrol diabetes mellitus, mencegah komplikasi. ${ }^{(8)}$ Upaya pemerintah dalam meningkatkan kesehatan masyarakat dengan beberapa program yang telah diberikan kepada pasien diabetes mellitus sampai saat ini masih berjalan, namun ada kendala yang dihadapi oleh pemerintah dalam program ini, seperti kurangnya kesadaran pasien dalam penanganan penyakitnya, petugas kesehatan yang dianggap kurang memadai, proses pelayanan yang dianggap rumit oleh pasien dan keluarga pasien. Hal ini diperkuat dengan penelitian yang menunjukan bahwa masih banyak pasien DM di Yogyakarta yang belum mendaftarkan diri $(60 \%)$ sebagai peserta program, dikarenakan beberapa faktor seperti kurangnya edukasi, sehingga berdampak pada ketidakfahaman akan informasi kesehatan dan program yang ditawarkan, kesulitan dalam akses pelayanan program yang ditawarkan dan kesadaran diri dalam penanganan penyakit yang masih rendah. ${ }^{(9)}$

Berdasarkan hasil wawancara dengan 15 pasien DM di Yogyakarta, didapatkan ketidaktahuan mereka dalam penanganan dan pencegahan keluhan yang mereka rasakan seperti kram dan rasa kebas pada kaki. Belum terpaparnya informasi tentang penanganan, pencegahan komplikasi kaki DM dan ketidak cukupan waktu, kesibukan pekerjaan yang dikeluhkan oleh perawat sehingga resiko tinggi komplikasi terutama pada kaki dapat terjadi. Oleh sebab itu, berdasarkan fenomena tersebut diatas peneliti merasa sangat penting untuk melakukan penelitian tentang pengaruh edukasi senam kaki terhadap self care pada pasien DM.

\section{METODE}

Penelitian ini merupakan penelitian kuantitatif, dengan desain penelitian eksperimen kuasi yaitu pre-test and post-test with control group design, yaitu peneliti menganalisis dan membandingkan pengaruh edukasi senam kaki terhadap self care pada pasien DM di kelompok intervensi dan kelompok kontrol.

\begin{tabular}{llllll}
\hline Kelompok & Pretest & Perlakuan & Posttest \\
Intervensi & 01 & $\rightarrow$ & $\mathrm{X}$ & $\rightarrow$ & 02 \\
Kontrol & 03 & $\rightarrow$ & - & $\rightarrow$ & 04 \\
\hline
\end{tabular}

Gambar 1. Desain penelitian

Populasi dalam penelitian ini adalah seluruh pasien DM di RSUD Panembahan Senopati Bantul Yogyakarta. Total pasien DM rawat inap dari bulan Januari sampai April 2017 adalah 396 orang. Teknik pengambilan sempel dalam penelitian ini adalah purposive sampling, yaitu teknik penentuan sampel dengan pertimbangan tertentu sesuai dengan kriteria inkklusi yang ditetapkan oleh peneliti. Ukuran sampel adalah 64 (dibagi menjadi kelompok intervensi dan kelompok kontrol masing-masing 32 pasien), selanjutnya dilakukan perlakuan edukasi senam kaki sebanyak 5 kali, kemudian diukur kemampuan pasien DM dalam melakukan senam kaki menggunakan kuesioner. Data dianalisis menggunakan paired sample t-test.

\section{HASIL}

Tabel 1 merupakan penyajian hasil analisis data penelitian. 
Tabel 1. Hasil uji pengaruh edukasi senam kaki terhadap self care pada pasien DM

\begin{tabular}{|c|c|c|c|c|c|c|c|}
\hline Kelompok & & $\mathrm{n}$ & Min-Max & Mean & Mean Differance & SD & Asymp.sig (2-tailled) \\
\hline \multirow{2}{*}{ Intervensi } & Pre & \multirow{2}{*}{32} & $16-30$ & 21,50 & \multirow{2}{*}{$-9,19$} & 3,121 & \multirow{2}{*}{0,000} \\
\cline { 2 - 4 } \cline { 4 - 5 } & Post & & $22-35$ & 30,69 & & 2,455 & \\
\hline \multirow{2}{*}{ Kontrol } & Pre & \multirow{2}{*}{32} & $15-26$ & 20,81 & \multirow{2}{*}{$-0,69$} & 2,334 & \multirow{2}{*}{0,534} \\
\cline { 2 - 4 } & Post & & $16-27$ & 21,50 & 2,676 & \\
\hline
\end{tabular}

Tabel 1 menunjukan bahwa terjadi peningkatan self care senam kaki dilihat dari hasil perhitungan pada kelompok intervensi, yakni mean difference sebesar -9,19; yang artinya terdapat selisisih peningkatan sebelum dan sesudah dilakukan intervensi sebesar 9,19; dengan p-value 0,000; yang berarti terdapat perubahan yang bermakna. Sedangkan pada self care senam kaki kelompok kontrol didapatkan mean difference sebesar -0,69; dengan $p$-value 0,534 ; yang artinya tidak terjadi perubahan yang bermakna.

\section{PEMBAHASAN}

Pasien dengan kondisi penyakit kronis seperti DM memerlukan suatu sistem pembelajaran yang bersifat continue dan terbuka sehingga pasien mampu melakukan self care dengan baik. Hal ini dibenarkan oleh teori Orem yang menyebutkan bahwa seseorang memiliki kemampuan dasar untuk melakukan perawatan terhadap dirinya sendiri. Pencegahan komplikasi kaki diabetikum yang berpotensi pada ulkus diabetikum yang pada akhirnya terjadi amputasi pada kaki, hanya saja mereka memiliki keterbatasan dalam perawatan tersebut seperti keterbatasan informasi, sehingga perawat memiliki tanggung jawab untuk memberikan edukasi kepada pasien sehingga berdampak pada minimalnya kejadian komplikasi. Hal tersebut sesuai dengan teori yang diungkapkan oleh Orem bahwa salah satu metode yang digunakan dalam ke 6 metode untuk meningkatkan self care pada pasien adalah dengan cara pemberian edukasi.

Pasien DM yang tidak dikelola dengan baik akan meningkatkan resiko terjadinya komplikasi dikarenakan pada pasien DM rentan mengalami komplikasi yang diakibatkan karena terjadi defisiensi insulin atau menurunnya kerja insulin yang tidak adekuat. Komplikasi yang ditimbulkan bersifat akut maupun kronik dimana komplikasi akut terjadi berkaitan dengan peningkatan kadar gula darah secara tiba-tiba, sedangkan komplikasi kronik sering terjadi akibat peningkatan gula darah dalam waktu yang cukup lama.

\section{KESIMPULAN}

Berdasarkan penelitian yang telah dilakukan, disimpulkan bahwa edukasi senam kaki berpengaruh positif terhadap self care pada pasien diabetes mellitus.

\section{DAFTAR PUSTAKA}

1. American Diabetes Association. Diabetes Care [Internet]. 2017 [cited 2017 Aug 19]. Available from: http://www.ncbi.nlm.gov/pmc/articles

2. $\quad$ Dinkes Prov. DIY. Data Prevalensi Pasien Diabetes Mellitus DIY. Yogyakarta: Dinkes Prov. DIY; 2015.

3. Kemenkes RI. Riset Kesehatan Dasar (RISKESDAS) 2018. Jakarta: Kemenkes RI; 2018.

4. RSUD Panembahan Senopati Bantul. Laporan Informasi Rumah Sakit (SIRS) RSUD Panembahan Senopati Bantul Yogyakarta. Bantul: RSUD Panembahan Senopati Bantul; 2017.

5. Orem DE. Nursing Concept Of Practice. (6th ed). St. Louis: The CV Mosby Harcourt Sciences Company; 2001.

6. Junianty S. Hubungan Tingkat Self Care Dengan Kejadian Komplikasi pada Pasien DM Tipe 2 di Ruang Rawat Inap RSUD Jawa Barat. Thesis. Bandung: Universitas Padjajaran; 2012.

7. Ayele K, Tesfa B, Abebe L, Tilahun T, Girma E. Self care behavior among patients with diabetes in Harari, Eastern Ethiopia: the health belief model perspective. Plos One. 2012;7(4):1-6.

8. RS Cahya Kawallyan. Latihan Senam Kaki Untuk Penderita Diabetes Mellitus. Kawallyan: RS Cahya Kawallyan; 2008.

9. Kusniawati. Analisis Faktor yang Berkontribusi Terhadap Self Care Diabetes pada Klien Diabetes Mellitus Tipe 2 Di Rumah Sakit Umum Tangerang. Thesis. Jakarta: Universitas Indonesia; 2011. 